\title{
Correction to: Study of the Formic Acid Electrooxidation on Rhodium on Steady State Using a Flow Cell: Potential Dependence of the CO Coverage
}

\author{
Gisela C. Luque $^{1} \cdot$ María A. Montero $^{1} \cdot$ María R. Gennero de Chialvo ${ }^{1}$ (D) $\cdot$ Abel C. Chialvo $^{1}$ (D) \\ Published online: 21 September 2020 \\ (C) Springer Science+Business Media, LLC, part of Springer Nature 2020
}

\section{Correction to: Electrocatalysis}

https://doi.org/10.1007/s12678-020-00599-7

In the original publication of the article, there is a mistake regarding the adsorbed reaction intermediate $\mathrm{HCOO}_{\mathrm{ad}}$, which is correctly written in the equations, but in the text it is wrongly written as $\mathrm{COOH}_{\mathrm{ad}}$.

Publisher's Note Springer Nature remains neutral with regard to jurisdictional claims in published maps and institutional affiliations.

The online version of the original article can be found at https://oi.org/ 10.1007/s12678-020-00599-7

\footnotetext{
Abel C. Chialvo

achialvo@fiq.unl.edu.ar

Gisela C. Luque

luquegc@gmail.com

María A. Montero

mmontero@fiq.unl.edu.ar

María R. Gennero de Chialvo

mchialvo@ fiq.unl.edu.ar

1 Programa de Electroquímica Aplicada e Ingeniería Electroquímica, PRELINE (FIQ-UNL), Instituto de Química Aplicada del Litoral, IQAL (UNL-CONICET), Santiago del Estero 2829, 3000 Santa

$\mathrm{Fe}$, Argentina
} 